\title{
Identification of Stellantchasmus falcatus Metacercariae Encysted in Mullets in Korea
}

\author{
Jong-Yil Chai and Woon-Mok Sohn \\ Department of Parasitology and Institute of Endemic Diseases, \\ College of Medicine, Seoul National University, Seoul 110-460, Korea
}

\begin{abstract}
A group of metacercariae encysted in the flesh of Mugil sp. were identified to be Stellantchasmus falcatus by the morphology of adult worms obtained experimentally. It is confirmed that mullets serve as a second intermediate host of this heterophyid fluke in Korea.
\end{abstract}

Key words: Stellantchasmus falcatus, Heterophyidae, intestinal fluke, mullets

Stellantchasmus falcatus (Trematoda; Heterophyidae), a small intestinal fluke of fish-eating birds and mammals, is an occasional parasite of humans in Korea (Seo et al., 1984; Hong et al., 1986), Japan (Kagei et al., 1964), Philippines (Africa et al., 1940), Thailand (Tantachamrun and Kliks, 1978) and Hawaii (Alicata and Schattenburg, 1938).

In Hawaii, Japan and China, brackish water snails such as Stenomelania newcombi or Thiara granifera and brackish water fishes such as mullets (Mugil sp., Liza menada) and gobies (Acanthogobius flavimanus, Gobius sp.) were reported to be its first (Noda, 1959) and second (Onji and Nishio, 1924; Alicata and Schattenburg, 1938; Kobayasi, 1968) intermediate hosts respectively. In Korea, however, intermediate hosts of $S$. falcatus were not extensively studied. Seo et al. (1979) discovered Stellantchasmus metacercariae from mullets, but the metacercariae were not definitely identified through obtaining adult worms. In the present study, a group of heterophyid metacercariae encysted in the flesh of Mugil sp. was identified to be $S$. falcatus by the morphology of adult worms obtained after experimental infection to albino rats.

In May 1986, total 10 Mugil sp., $20 \sim 30 \mathrm{~cm}$ long, were purchased from a local fisheries market in a southern part of Kyeongsang-namdo (Province). They were brought to the laboratory, and artificially digested to examine heterophyid metacercariae, especially $S$. falcatus. The metacercariae which were morphologically characterized by submedially located ventral sucker and elongated seminal vesicle(expulsor) (Fig. 1) were tentativly diagnosed as $S$. falcatus. Three mullets were found infected with $S$. falcatus, from which a total of 470 metacercariae were collected. They were $0.15 \sim 0.20 \mathrm{~mm}$ by $0.13 \sim 0.19 \mathrm{~mm}$ in size and round to elliptical in shape (Fig. 1). Most of the metacercariae were found from muscles and a few were from the head and gill.

Among them 280 were used to infect 5 rats (Sprague-Dawley), $30 \sim 100$ to each rat, and $7 \sim$ 10 days later the rats were sacrificed to harvest worms from their intestinal tract. Total 83 adult worms $(29.6 \%$ of infected) were harvested.

Morphologically the worms were compatible with $S$. falcatus, both in measurements and descriptions (Onji and Nishio, 1924; Seo et al., 1984). They were $0.41 \sim 0.70 \mathrm{~mm}$ long and $0.32 \sim 0.39 \mathrm{~mm}$ wide, and beset with minute scale-like spines(Fig. 2). They were characterized by the presence of ventrogenital sac (Fig. 

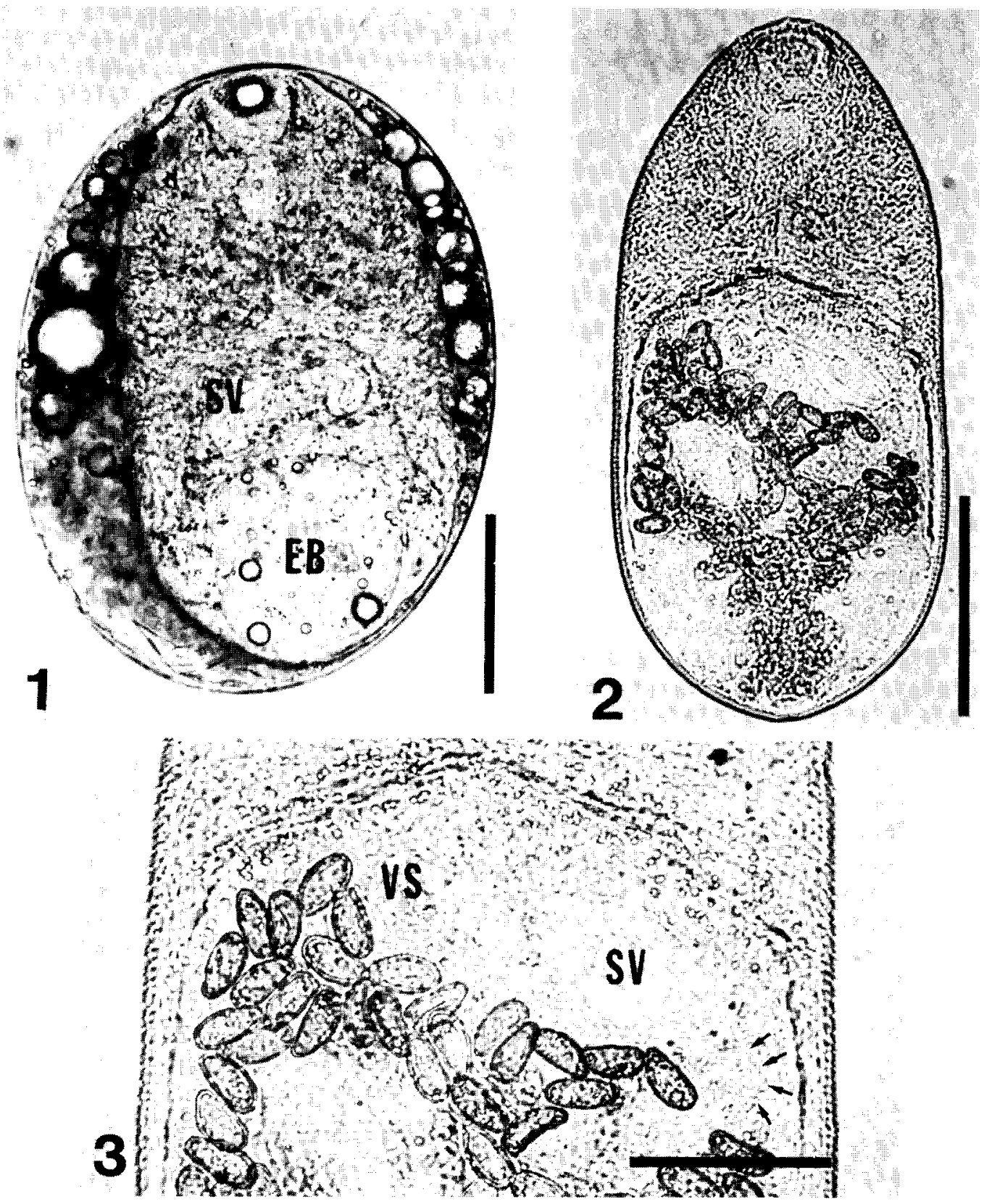

Fig. 1. Metacercaria of $S$. falcatus collected from a mullet, dorsal view(Scale: $50 \mu \mathrm{m}$ ). Note the elongated seminal vesicle (SV) and round excretory bladder (EB).

Fig. 2. Adult worm of $S$. falcatus recovered from an experimental rat 7 days after infection (Scale: $200 \mu \mathrm{m}$ ).

Fig. 3. Magnification of Fig. 2 near the ventrogenital sac (VS) and seminal vesicle(SV), which consists of a muscular expulsor and a vesicular part(arrows) (Scale: $100 \mu \mathrm{m}$ ). 
3) containing ventral sucker armed with minute spines (less than $1 \mu \mathrm{m}$ ) on its inner rim, and of seminal vesicle consisted with an elongated muscular expulsor and a round vesicular part (arrows in Fig. 3).

As to the taxonomy of Stellantchasmus spp., at least 4 species had been reported before Chen(1951), who reduced them to only one species, $S$. falcatus. The reduction is agreed, or followed, by succeeding authors (Pearson, 1964; Seo et al., 1984). Another species, $S$. aspinosus, was proposed by Pearson(1964), with the differential morphology of unarmed and little modified ventral sucker in $S$. aspinosus.

$S$. falcatus is, like other heterophyid flukes such as Haplorchis spp. and Procerovum calderoni, one of the potent pathogenic agents of extraintestinal (cardiac, cerebral and spinal) heterophyidiasis in man (Africa et al., 1940). Nevertheless, host-parasite relationships in heterophyid infections, especially in terms of pathophysiological and immunological aspects of extraintestinal parasitism, have never been studied in detail. Since human infection with S. falcatus or other heterophyid flukes seems not uncommon in areas where brackish water fishes are eaten raw and cases are expected to increase, studies on host-parasite relationships are greatly needed.

The present study confirmed that the mullet serves as a second intermediate host of $S$. falcatus in Korea.

\section{REFERENCES}

Africa, C.M., de Leon, W. and Garcia, E.Y.(1940) Visceral complications in intestinal heterophyidiasis of man. Acta Med. Philippina, Monogr, Ser. No. 1:1-132.

Alicata, J.E. and Schattenburg, O.L. (1938) A case of intestinal heterophydiasis of man in Hawaii.
J. Am. Med. Ass., 110(14):1,100-1, 101 .

Chen, H.T. (1951) Stictodora manilensis and Stellantchasmus falcatus from Hong Kong with a note on the validity of other species of the two genera (Trematoda: Heterophyidae). Lingnan Sci. J., 23:165-175.

Hong, S.T., Chai, J.Y. and Lee, S.H. (1986) Ten human cases of Fibricola seoulensis infection and mixed one with Stellantchasmus and Metagonimus. Korean J. Parasit., 24(1):94-96.

Kagei, N., Oshima, T., Ishikawa, K. and Kihata, M. (1964) Two cases of human infection with Stellantchasmus falcatus Onji et Nishio, I915 (Heterophyidae) in Kochi Prefecture. Jap. J. Parasitol., 13(6):472-478 (in Japanese).

Kobayasi, H. (1968) Studies on trematoda in Hainan Island, South China and Viet-Nam(French IndoChina). Reports of scientifical works by $\mathrm{H}$. Kobayasi, pp. 155-251.

Noda, K.(1959) The larval development of Stellantchasmus falcatus(Trematoda: Heterophyidae) in the first intermediate host. J. Parasit., 45:635642.

Onji, Y. and Nishio, T. (1924) A monograph of intestinal trematodes. Chiba Igakkai Zasshi, 2(3): 113-161 (in Japanese).

Pearson, J.C. (1964) A revision of the subfamily Haplorchinae Loose, 1899 (Trematoda: Heterophyidae) I. The Haplorchis group. Parasitology, 54: 601-676.

Seo, B.S., Cho, S.Y., Chai, J.Y. and Hong, S.T. (1979) Identification of the metacercariae of Heterophyes sp. and Stellantchasmus sp. from mullets of Yongsan River and Geoje Do. Korean $J$. Parasit., 17(2):165-166 (Abstract in Korean). Seo, B.S., Lee, S.H., Chai, J.Y. and Hong, S.J. (1984) Studies on intestinal trematodes in Korea XII. Two cases of human infection by Stellant. chasmus falcatus. Korean J. Parasit., 22(1):43-50.

Tantachamrun, T. and Kliks, M. (1978) Heterophyid infection in human ileum: Report of three cases. Southeast Asian J. Trop. Med. Publ. Hlth., 9(2): 43-50. 
$=$ 국문초록 $=$

\title{
남해산 숭어(崇魚)에서 검출된 Stellantchasmus falcatus 피낭유충의 동정
}

\author{
서울대학교 의과대학 기생충학교실 및 풍토병연구소 \\ 채 종 일 - 손 운 목
}

경상남도 남해 지방산 충어에서 Stellantchasmus falcatus의 피낭유충을 발견하고 흰쥐에 감염시킨 후 성충을 얻어 동정하였다. 검사한 숭어는 모두 10 마리로서 크기 $20 \sim 30 \mathrm{~cm}$ 이었고 그중 3 마리에서 S. falcatus로 생각되는 피낭유충이 470 개 검출되었다. 피낭유충은 원형 또는 타원형으로 크기 $0.15 \sim 0.20 \times 0.13 \sim 0.19 \mathrm{~mm}$ 이었고 대부분 이 숭어의 근육에서 발견되었다.

총 280 개의 피낭유충을 횐쥐 5 마리에 각각 $30 \sim 100$ 개씩 나누어 감염시키고 $7 \sim 10$ 일후에 흰쥐를 희생시켜 소장 (小腸) 내용물을 검경한 바 충 83마리의 성충이 회수되었다. 회수된 충체는 길이 $0.41 \sim 0.70 \mathrm{~mm}$, 폭 $0.32 \sim 0.39$ $\mathrm{mm}$ 이었고, 장낭형 (長整型; elongated sac-like)의 expulsor를 가진 저정낭 (seminal vesicle) 등 몇가지 형태학 적 특징을 근거로 S. falcatus Onji et Nishio, 1915로 동정되었다.

이 뎐구로 우리나라에서도 숭어가 S. falcatus의 제 2 중간숙주역할을 하고 있음이 확인되었고 이 홉충의 인체 감염원이 되고 있을 것으로 추측되었다. 